FOLIA HISTORICA CRACOVIENSIA, 20: 2014, s. 155-177

DOI: http://dx.doi.org/10.15633/fhc.652

Wojciech Paduchowski

Instytut Pamięci Narodowej Oddzią w Krakowie

\title{
Galicyjskie górnictwo i hutnictwo w świetle Powszechnej Wystawy Krajowej we Lwowie w 1894 roku
}

Powszechna Wystawa Krajowa, zwana też kościuszkowską z racji odbywania się jej w setną rocznicę insurekcji kościuszkowskiej, miała być niejako odpowiedzią na dzieło Stanisława Szczepanowskiego z 1888 roku pt. Nędza Galicji $w$ cyfrach ${ }^{1}$. Miała pokazać niewątpliwy postęp ekonomiczny i kulturowy Galicji od czasu uzyskania autonomii i stać się przeciwwagą dla obrazu przedstawionego przez Szczepanowskiego. Dla Polaków stanowiła jednak przede wszystkim „obrachunek sumienia” na polu działalności organicznej, sposób na integrację narodową nie tylko Polaków z Galicji, ale również z pozostałych zaborów, a także dla tych, których życie pchnęło w różne zakątki globu, czego przykładem był na wystawie m.in. Pawilon Amerykański. Wystawa stanowiła także przyczynek do pobudzenia świadomości narodowej i potrzeby edukacji wśród ludu, czego przykładem były licznie organizowane wycieczki dzieci włościańskich². Również Ukraińcy uważali Wystawę za swoją własną. Na jej

${ }^{1}$ Nędza Galicji w cyfrach stała się wyzwaniem dla współczesnych Szczepanowskiemu galicyjskich działaczy i polityków, zob. K. Broński, Rozwój gospodarczy większych miast galicyjskich w okresie autonomii. Kraków 2003, s. 9. Powszechna Wystawa Krajowa we Lwowie w 1894 roku była również odpowiedzią na pracę Tadeusza Rutowskiego W sprawie przemysłu krajowego z 1883 roku.

${ }^{2}$ Wyjazdy na wystawę dzieci chłopskich organizowało przede wszystkim Towarzystwo Szkoły Ludowej, ale również np. Towarzystwo Pedagogiczne w Żółkwi i inne społeczne towarzystwa, stowarzyszenia, komitety itp. Finansowanie wyjazdów odbywało się przeważnie z dobrowolnych datków. Tym, który zapoczątkował całą akcję, był Jakub Bojko. Organizacją wyjazdów na Wystawę zajmował się również dr Henryk Jordan (na Wystawę udała się młodzież uczęszczająca do parku jego imienia). Zob. „Kurier Lwowski” R. 12: 1894: dodatek do numeru 134 z dn. 21 V; nr 147 z dn. 29 V, s. 2; $\mathrm{nr} 158 \mathrm{z}$ dn. 9 VI, s. 1; $\mathrm{nr} 161 \mathrm{z}$ dn. 12 VI, s. 1; nr $183 \mathrm{z}$ dn. 4 VII, s. 5. Wystawa wpisywała się w szeroki program podniesienia poziomu ogólnego ludu, czego efektem było m.in. to, że od początku XX wieku synowie chłopscy stanowili już około 20 proc. ogółu studiujących. Zob. M. Kulczykowski, Modernizacja społeczeństwa galicyjskiego w warunkach autonomii politycznej. 
otwarciu powitalną przemowę wygłosił, obok księcia Adama Sapiehy, dr Damian Sawczuk (po ukraińsku).

Iwan Franko niewątpliwie słusznie zauważył: „Z wystawy wykluczono wszystkie nasze choroby, a pokazano tylko broń, jaką mamy do ich zwalczania [...] ale dość, że budujemy, że pracujemy, że się uczymy, że się nie zamykamy na świat, że postępujemy naprzód, $\mathrm{z}$ biedą powoli, nierównomiernie, bezładnie nieraz, ale postępujemy"3. Wystawa bowiem nie prezentowała negatywnych zjawisk. Z założenia miała pokazać wszystko, co najlepsze, i tym samym pokazać to, czego nie zaprezentowano lub pokazano tylko w skromnym rozmiarze, niedostatki, niedociągnięcia, a nawet zacofanie.

Powszechna Wystawa Krajowa miała objąć swoim zakresem życie duchowe i materialne mieszkańców Galicji i nie tylko, w tym przede wszystkim Polaków, dać przykłady bogactwa jej płodów, górnictwa, hutnictwa, rolnictwa, leśnictwa, łowiectwa. Przedstawić życie ludności, zabytki sztuki ludowej, tzw. przemysł domowy, rękodzieła; pokazać rozwój instytucji finansowych, administracji publicznej, opieki zdrowotnej, komunikacji, inżynierii, budownictwa, literatury, szkolnictwa ogólnego i zawodowego, rozwój sztuk pięknych i architektury.

Nie sposób przedstawić bogactwa Wystawy w jednym artykule, dlatego też skoncentruję się tylko na dwóch jej aspektach, a mianowicie na zaprezentowaniu osiągnięć Galicji w dziedzinie górnictwa oraz hutnictwa. Zanim jednak przejdę do prezentacji samej Powszechnej Wystawy oraz w szczególności powyższych dziedzin, chciałbym przedstawić zarys historyczny wystawiennictwa galicyjskiego poprzedzającego Wystawę z 1894 roku.

Już od 1850 roku, tj. od pierwszych poważniejszych wystąpień C.K. Galicyjskiego Towarzystwa Gospodarskiego, starano się przez urządzanie wystaw we Lwowie, Krakowie i większych miastach prowincjonalnych wspomagać ekonomiczny rozwój Galicji, przede wszystkim w zakresie produkcji rolniczej i wiążącego się z nią chowu żywego inwentarza. Nie było to zaskoczeniem, skoro kraj był rolniczy, a aż trzy czwarte ludności Galicji utrzymywało się z produkcji rolniczej4. Od pierwszej czterodniowej wystawy zwierząt domowych i narzędzi rolniczych we Lwowie w roku 1850 C.K. Galicyjskie Towarzystwo Gospodarskie urządzało we Lwowie i w mniejszych miastach coroczne (z wyjątkiem

W: Samomodernizacja społeczeństw w XIX wieku. Irlandczycy, Czesi, Polacy. Pod red. L. Trzeciakowskiego, K. Makowskiego. Poznań 1999, s. 117.

3 „Kurier Lwowski” R. 12: 1894, nr 239 z dn. 29 VIII, s. 2.

${ }^{4}$ F. Bujak, Wieś zachodniogalicyjska u schyłku XIX w. Lwów 1904, s. 63. 
lat 1863-1866) wystawy owoców, zbóż i ziemiopłodów, zwierząt domowych i narzędzi rolniczych, specjalne wystawy nasion, chmielu, bydła rozpłodowego i koni roboczych. Wszystkie te wystawy, choć cenne, były wystawami małymi (powiatowymi) i nie spełniały oczekiwań wystawców i odwiedzających. O małej skali wystaw świadczy fakt, że na pierwszej wystawie rolniczej we Lwowie zaprezentowano tylko 15 sztuk bydła rogatego, nie wystawiając koni. Po raz pierwszy konie pojawiły się w 1852 roku na wystawach rolniczych we Lwowie, Rzeszowie i Stanisławowie, jednakże tylko po kilka lub kilkanaście sztuk. Z czasem jednak małe powiatowe wystawy rozrastały się. Do najbardziej udanych wystaw tego typu zaliczano tarnowskie, zorganizowane w 1853 i 1854 roku z inicjatywy Władysława Sanguszki. Zgromadzono tam około 60 sztuk bydła i 30 sztuk inwentarza żywego. Pierwsze narzędzia i maszyny rolnicze produkowane w Galicji dopełniały wystawę. Jeszcze więcej okazów zgromadziła i większe zainteresowanie wzbudziła wystawa rolnicza urządzona w 1856 roku w Przemyślu z ramienia komitetu Galicyjskiego Towarzystwa Gospodarskiego przy współudziale ks. Adama Sapiehy i Seweryna Smaszewskiego. Zaprezentowało się na niej 18 obór z 106 sztukami bydła i ponad 100 sztukami owiec 5 .

Te wszystkie chwalebne, lecz drobne starania mające na celu usprawnienie produkcji rolniczej w zakresie gospodarstwa wiejskiego wzbudziły ogólne zainteresowanie wystawami. Przyczyniła się do tego również wystawa wiedeńska z roku 1873 roku, pierwsza w monarchii austro-węgierskiej urządzona na tak wielką skalę, którą wielu mieszkańców Galicji miało okazję widzieć i podziwiać6. Miało to znaczenie niebagatelne, ponieważ wiodącym źródłem inspiracji dla Galicji w różnych dziedzinach życia był przede wszystkim Wiedeń7. Wystawa ta niewątpliwie dodała odwagi Galicjanom, którzy w 1877 roku podjęli się organizacji wystawy we Lwowie, obejmującej zakresem nie tylko produkcję rolniczą, ale również przemysłową (przede wszystkim tzw. przemysł drobny, rękodzielniczy). Urządzono ją pod kierownictwem hr. Włodzimierza Dzieduszyckiego przy współudziale ks. Adama Sapiehy, Bolesława Augustynowicza,

\footnotetext{
${ }^{5}$ Powszechna Wystawa Krajowa 1894 r. i siły produkcyjne kraju, T. 1, z. 1. Lwów 1897, s. 52-53.

${ }^{6}$ Powszechna Wystawa w Wiedniu z 1873 roku korzystała już z dużego dorobku wystaw powszechnych odbywających się od 1851 roku: w Londynie, w 1855 roku w Paryżu, w 1862 roku ponownie w Londynie, w 1867 roku znów w Paryżu, piątą w kolejności była wiedeńska z 1873 roku. Zob. Przegląd Wystawy Powszechnej w Wiedniu w 1873. Pod red. S. Kossutha. Warszawa 1875, s. 1.

${ }^{7} \mathrm{~K}$. Broński, Galicja w dobie autonomii wobec wyzwań nowoczesności. W: Między zacofaniem a modernizacją. Społeczno-gospodarcze problemy ziem polskich na przestrzeni wieków. Pod red. E. Kościk, T. Głowińskiego. Wrocław 2009, s. 397.
} 
Ludwika Wierzbickiego i innych. Wystawiennictwo lwowskie postanowiono wpisać w ideę miast-ogrodów, urządzając wystawę krajową w 1877 roku na obszernym (ok. 8,5 ha) placu, tzw. ogrodzie Jabłonowskich. Ideę tę kontynuowano w roku Powszechnej Wystawy Krajowej w 1894 roku, jak również już w II RP w postaci lwowskich Targów Wschodnich. Wystawa trwająca od 6 września do 10 października zgromadziła bardzo liczne grono zwiedzających. Jak stwierdzano, stanowiła zachętę do niejednego pożytecznego przedsięwzięcia, które przyczyniło się do rozwoju rolnictwa i przemysłu galicyjskiego8.

Późniejszymi wystawami zorganizowanymi na większą skalę były okręgowa wystawa rolniczo-przemysłowa w Przemyślu z 1883 roku i wystawa krajowa w Krakowie z 1887 roku. Pierwsza z nich, zorganizowana pod przewodnictwem ks. Adama Sapiehy, oceniana była bardzo dobrze. Natomiast wystawa krakowska, która była planowana na znacznie większą skalę, jako wystawa krajowa, pomimo aktywnego przewodnictwa hr. Artura Potockiego nie zdołała się rozwinąć m.in. z powodu powtarzających się pogłosek wojennych. Do najlepszych jej działów zaliczano: etnograficzny, przemysłu domowego, szkół przemysłowych i warsztatów, jak również wystawę sztuk pięknych urządzoną w salach Sukiennic krakowskich. Powyższy katalog wystaw należałoby uzupełnić o jeszcze znaczniejsze wystawy specjalistyczne: wystawy stałe i czasowe sztuk pięknych organizowane przez Towarzystwo Przyjaciół Sztuk Pięknych w Krakowie i we Lwowie, wystawę etnograficzną oddziału czarnomorskiego Towarzystwa Tatrzańskiego w Kołomyi, wystawę higieniczno-lekarską z roku 1888 oraz przemysłu budowlanego z roku 1892, obie zorganizowane we Lwowie?.

Korzystając z dotychczasowego doświadczenia przede wszystkim wystaw przemyskiej (1883), krakowskiej (1887), wiedeńskiej (1877) czy też praskiej $(1891)^{10}$, galicyjscy działacze gospodarczy postanowili urządzić największą do tej pory powszechną wystawę w Galicji i zorganizować ją w roku 1894 we Lwowie. Staraniem Towarzystwa Kupców i Przemysłowców idea zorganizowania wystawy znalazła poparcie wśród rozmaitych wpływowych kół. W 1892 roku w sali ratuszowej we Lwowie prezesostwo Wystawy powierzono długoletniemu prezesowi Galicyjskiego Towarzystwa Gospodarskiego ks. Adamowi Sapiesze. Wiceprezesami zostali hr. Stanisław Badani (członek izby Panów), August

\footnotetext{
${ }^{8}$ Powszechna Wystawa Krajowa 1894..., s. 53-54.

9 Tamże, s. 54-55.

${ }^{10}$ Przy opisywaniu źródeł doświadczeń, z jakich korzystano przy organizacji Wystawy z 1894 roku, nie wymieniano wielkiej wystawy paryskiej z 1889 roku.
} 
Galicyjskie górnictwo i hutnictwo w świetle Powszechnej Wystawy Krajowej... 159

Gorayski (poseł sejmowy), Edmund Mochnacki (prezydent miasta Lwowa) oraz Feliks Szlachtowski (prezydent miasta Krakowa). Dyrektorem Wystawy został dr Zdzisław Marchwicki. Sekretarzami zostali Juliusz Starkel oraz Jan Kazimierz Zieliński. Skarbnikiem wybrano dr. Alfreda Górskiego, prezesem wydziału finansowego został Antoni Jaxa Chamiec, budowlanego - Julian Zacharewicz. Naczelnym inżynierem Wystawy był Józef hr. Lubieński, a naczelnym architektem Franciszek Skowron ${ }^{11}$.

Wystawę zorganizowano w parku im. Jana Kilińskiego (Park Stryjski) - zajmowała ona obszar ok. 25 ha i była podzielona na 28 sekcji ${ }^{12}$. Na terenie wystawy znajdowało się około 129 różnego rodzaju budowli, w tym m.in.: gmach przemysłowy, hale maszyn, pałac sztuki, stadion, gmach Panoramy Racławickiej, stajnie dla koni ${ }^{13}$. Wystawa zorganizowana była w systemie pawilonowym. Do największych atrakcji wystawy należały m.in. wymieniona już i pokazana tu po raz pierwszy Panorama Racławicka, wieża wodna, elektryczna kolorowa fontanna, linowa kolej napowietrzna oraz tramwaj elektryczny ${ }^{14}$.

Organizatorom wystawy zależało na tym, aby cała Galicja była na niej reprezentowana. Dlatego też we wszystkich ważniejszych miastach ustanowiono komitety lokalne oraz wybrano delegatów powiatowych. Uchwalono również „odezwę do Kraju”, którą w liczbie 120 tys. egzemplarzy rozesłano do wszystkich polskich i ukraińskich dzienników. Odezwa kończyła się bardzo wymownie: „Miłość kraju poczęła to dzieło, honor i pożytek kraju będą hasłem pracy, nad jego szczęśliwym dokonaniem" ${ }^{15}$. Odezwę podpisali prezes, wiceprezesowie oraz dyrektor Wystawy.

Wystawa trwała od 5 czerwca do 16 października. Miała własną straż pożarną, służbę telefoniczną, telegraficzną i pocztową (ruch pocztowo-telefoniczny był porównywalny $\mathrm{z}$ ruchem $\mathrm{w}$ małym mieście galicyjskim) ${ }^{16}$. Zorganizowano

${ }^{11}$ Powszechna Wystawa Krajowa 1894..., s. 56-66.

${ }^{12}$ Powszechna Wystawa Krajowa we Lwowie. Regulamin Organizacyjny Komitetu głównego powszechnej Wystawy Krajowej we Lwowie roku 1894. Lwów 1892, s. 1-3.

${ }^{13}$ Powszechna Wystawa Krajowa 1894... (Ostateczny Plan Sytuacyjny Powszechnej Wystawy Krajowej we Lwowie 1894).

${ }^{14}$ Tramwaj elektryczny miał funkcjonować we Lwowie już od 1893 roku, zob. K. Broński, Galicja $w$ dobie autonomii..., s. 402.

${ }^{15}$ Powszechna Wystawa Krajowa 1894 r..., s. 71.

${ }^{16}$ Nadano 49265 przesyłek, odebrano 54 946. Nadano 4538 telegramów, odebrano 2282. Z placu Wystawy wykonano 2680 rozmów telefonicznych. Zob. Powszechna Wystawa Krajowa $1894 \ldots$, s. 130-131. 
również loterię wystawową ${ }^{17}$. Na Wystawie działały 32 pawilony gastronomiczne, jednakże największą rolę odgrywały trzy restauracje - dwie wiedeńskie i tylko jedna lwowska, Jana Baczyńskiego ${ }^{18}$. Wystawa była oświetlana elektrycznie. Montażem i stroną techniczną instalacji elektrycznej zajmowała się firma Franciszka Křžika z Pragi. Technicznym problemem było doprowadzenie wody na teren Wystawy - kłopot wynikał z dużej różnicy poziomów terenu. Rozwiązano go za pomocą trzech pomp parowych, które dostarczały do $600 \mathrm{~m}^{3}$ wody na dobę do wieży wodnej, zbudowanej na kształt baszty średniowiecznej, o wysokości $18 \mathrm{~m}$ i pojemności 60 tys. $\mathrm{m}^{3}$. Wodociąg, ponad 6 tys. metrów rur, zbudowała krakowska fabryka Leona Zieleniewskiego ${ }^{19}$. Koszty wszystkich robót na wystawie, prócz instalacyjnych i dekoracyjnych, wyniosły ponad milion złotych reńskich (złr). Organizatorzy Wystawy byli liczącymi się pracodawcami: średnio od 1 maja 1893 do 4 czerwca 1894 roku przy robotach na placu budowy pracowało dziennie 681 osób i 22 fury konne ${ }^{20}$.

Wystawa stała się okazją do organizacji wielu zjazdów, bankietów, kongresów różnych towarzystw i stowarzyszeń. Była to wyraźna oznaka silnego angażowania się Polaków w życie społeczno-gospodarcze Galicji. W czasie trwania Wystawy odbywały się imprezy towarzyszące: III Zjazd Techników Polskich, II Zjazd Sokołów, Kongres Pedagogów Polskich, Zjazd Towarzystwa Pedagogicznego, Zjazd Towarzystwa Szkoły Ludowej, Zjazd Towarzystwa Nauczycieli Szkół Wyższych, II Zjazd Dziennikarzy i Literatów Polskich, Zjazd Lekarzy i Przyrodników, bankiet na cześć Stefana Cegielskiego, VII Zjazd Gorzelników, Zjazd Młynarzy Galicyjskich, I Zjazd Straży Skarbowej, Zjazd Sto-

${ }_{17}$ Loteria miała do sprzedania 600 tys. losów po 1 złr (co odpowiadało 2 markom lub 2,5 frankom). Suma wygranych wynosiła 118 tys. złr. Wszystkie nagrody były zakupione w Galicji. Pierwszą nagrodą była kamienica we Lwowie o wartości 60 tys. złr, drugą brylanty o wartości 20 tys. złr. Jeżeli organizatorom loterii udało się sprzedać wszystkie losy, to łatwo obliczyć, że loteria przyniosła niebagatelny dochód 482 tys. złr. Zob. Powszechna Wystawa Krajowa..., s. 132.

${ }^{18}$ Wiedeńskie restauracje należały do Gerarda prowadzącego restaurację w Jockey-Klubie wiedeńskim oraz Zogelmanna mającego restaurację w Hotelu de France w Wiedniu. Poza tym na placu Wystawy znajdowały się m.in. cukiernia Szolca z Przemyśla, pawilon Goetza z Okocimia, kawiarnia Ważnego, kawiarnia arabska Brzezickiego, cukiernia Zimmera, pawilony sprzedaży wody sodowej Lityńskiego, pawilon sprzedaży wódek Bałłabana, pawilon firmy Brandstätter (pierniki i cukry), pawilon firmy Czyńskiego (pierniki), pawilon Jankowskiego (wędliny, gorące kiełbasy), pawilon spadkobierców Kiselki, pawilon Kondratowicza, mleczarnia, amerykański „saloon”, pawilon Górnego i Pilarskiego. Zob. Powszechna Wystawa Krajowa 1894..., s. 129-130.

19 Tamże, s. 136-142.

${ }^{20}$ Tamże, s. $147-148$. 
Galicyjskie górnictwo i hutnictwo w świetle Powszechnej Wystawy Krajowej... 161

warzyszenia „Gwiazda”, Zjazd Rękodzielników i Przemysłowców, IV Zjazd Kupców i Przemysłowców, Wiec Włościański, Zjazd Kółek Rolniczych, Zjazd C.K. Galicyjskiego Towarzystwa Gospodarskiego, Zjazd Towarzystwa Leśnego, Zjazd Ekonomistów, Zjazd Towarzystwa Prawniczego ${ }^{21}$.

Jedną z gałęzi górnictwa prezentowaną na wystawie była produkcja soli. Prawdziwe muzeum geologiczne, górnicze, a nawet historyczne zawierał oddział salinarny pawilonu ministerstwa finansów. W pawilonie prezentowano różnorodne okazy minerałów, jak również map, modeli i narzędzi. Świadczyły one dobitnie o tym, że galicyjskie górnictwo i warzelnictwo solne mają wiekową historię. Przedstawiono sztuczną grotę zrobioną z bloków i kryształów soli, pokrytą licznymi, specjalnie na wystawę wykonanymi mapami, planami górniczymi, przekrojami szybów oraz zestawieniami statystycznymi. Na szklanych płytach wykonano model geologiczny kopalni wielickiej, przedstawiono mapy i plany kopalni w Bochni i Wieliczce w skali 1:720 oraz modele warzelni ${ }^{22}$. Jednakże zaprezentowane piękne eksponaty solne nie oddawały prawdziwego stanu galicyjskiego górnictwa i produkcji solnej.

W Galicji produkowano dwa rodzaje soli: spożywczą oraz przemysłową. Do soli spożywczej w tym czasie zaliczano sól kamienną oraz sól warzoną. Produkowano również sole potasowe, w tym odrębny gatunek soli potasowej nawozowej - kainit. Ponadto na mocy ustawy z 1893 roku produkowano sól bydlęcą, która zawierała domieszkę piołunu i tlenku żelaza (o,75 proc.) - domieszka ta miała ją odróżnić od zwykłej soli pokarmowej i uczynić niezdatną do spożycia przez ludzi.

Stan galicyjskiej produkcji solnej obrazują dane statystyczne. Na przestrzeni piętnastu lat od 1877 roku (od poprzedniej wystawy lwowskiej) do roku 1892 produkcja soli w Galicji wzrosła o $170556^{23}$ cetn. metr., to jest o 17 055,6

${ }^{21}$ „Gazeta Narodowa” R. 34: 1894, nr 161 z dn. 10 VII, s. 2; nr 163 z dn. 12 VII, s. 2; nr 164 z dn. 13 VII, s. 2; nr $168 \mathrm{z}$ dn. 17 VII, s. 1-2; nr 169 z dn. 18 VII, s. 1-2; nr $170 \mathrm{z}$ dn. 19 VII, s. 1-2; nr $171 \mathrm{z}$ dn. 20 VII, s. 1-3; $\mathrm{nr} 172 \mathrm{z}$ dn. 21 VII, s. 2; $\mathrm{nr} 173 \mathrm{z}$ dn. 22 VII, s. 1-2; nr $175 \mathrm{z}$ dn. 24 VII, s. 2 oraz dodatek do „Gazety Narodowej”; nr 178 z dn. 27 VII, s. 2; nr 188 z dn. 7 VIII, s. 2 oraz dodatek do „Gazety Narodowej”; nr 194 z dn. 12 VIII, s. 2; nr 196 z dn. 14 VIII, s. 2; nr 197 z dn. 15 VIII, s. 2; nr 203 z dn. 21 VIII, s. 2; nr 204 Z dn. 22 VIII, s. 2; nr 210 z dn. 28 VIII, s. 1-2; nr 211 z dn. 29 VIII, s. 1-2; nr 212 z dn. 30 VIII, s. 2; nr 226 z dn. 13 IX, s. 2; nr 227 z dn. 14 IX, s. 2; nr 228 z dn. 15 IX, s. 2; nr 229 z dn. 16 IX, s. 1-2; nr 243 z dn. 30 IX, s. 2; nr 259 z dn. 16 X, s. 2 oraz dodatek do „Gazety Narodowej”.

${ }^{22}$ W. Szajnocha, Górnictwo, hutnictwo, przemysł naftowy, materiały budowlane. W: Powszechna Wystawa Krajowa we Lwowie w 1894. T. 1. Kraków 1896, s. 9-10.

${ }^{23}$ Obliczenia autora. 
ton, jednakże jej wartość pomimo wzrostu produkcji zmalała w tym czasie o $2122583^{24}$ złr. Co było tego przyczyną? Władysław Szajnocha, odpowiadając na to pytanie, stwierdzał, że powodem takiego stanu rzeczy było po pierwsze magazynowanie soli w pierwszym okresie, co powodowało wzrost jej ceny, i zaprzestanie magazynowania w późniejszym okresie, przez co jej cena spadła. Po drugie zaś przyczyniło się do tego zaprzestanie eksportu soli do Rosji, który w 1877 roku przyniósł 250 tys. złr $^{25}$. Zwiększenie produkcji soli w tym czasie było efektem przede wszystkim wzrostu produkcji soli przemysłowej (o prawie 400 proc. $)^{26}$, co wynikało $\mathrm{z}$ dużego popytu i rosnących potrzeb przemysłu chemicznego.

Galicja jako kraj przede wszystkim rolniczy powinna w dużej mierze być konsumentem soli przeznaczonej na cele hodowli i produkcji rolnej. Wspomniana tzw. sól bydlęca, mimo iż była tańsza niż sól spożywcza, nie znajdowała nabywców, przede wszystkim $\mathrm{z}$ powodu nadal zbyt wysokiej ceny ${ }^{27}$. Podobnie rzecz się miała $\mathrm{z}$ już wspomnianym kainitem, którego bogate pokłady posiadała Galicja w Kałuszu. Przed rokiem 1875 prywatne przedsiębiorstwo próbowało stworzyć tam wielką fabrykę soli potasowej. W 1884 roku skarb państwa podjął niejako na nowo próbę jej produkcji. W 1893 roku kainitu (mielonego) wyprodukowano zaledwie 29 tys. cetn. metr. ${ }^{28}(2900 \mathrm{t}$ ), w kawałkach 11 tys. cetn. metr. ( $1100 \mathrm{t}$ ). Była to cała produkcja soli potasowej w Galicji ${ }^{29}$. Nasuwa się w tym miejscu pytanie - podobnie jak w przypadku soli bydlęcej - o przyczynę małej skali produkcji. Tym razem Władysław Szajnocha nie szukał odpowiedzi w zbyt wygórowanej cenie, lecz upatrywał ją w barierach biurokratycznych. Aby legalnie nabyć kainit, należało spełnić wiele wymogów formalnych. Wystawa nie wyszła naprzeciw temu zadaniu. Nie było można na niej znaleźć szczegółowej pomocy (aktów prawnych), wskazówek, w jaki sposób przebrnąć przez gąszcz przepisów. Można było jedynie obejrzeć próbki kainitu ${ }^{30}$. W późniejszych latach jednakże (1894-1911)

${ }^{24}$ Obliczenia autora.

${ }^{25}$ W. Szajnocha, Górnictwo, hutnictwo..., s. 10.

${ }^{26}$ Obliczenia autora.

${ }^{27}$ W. Szajnocha, Górnictwo, hutnictwo..., s. 11.

${ }_{28}$ Tamże.

${ }^{29}$ J. Bar, P. Franaszek, Informator statystyczny do dziejów przemysłu w Galicji. Górnictwo i hutnictwo, produkcja, ceny, zbyt, przedsiębiorstwa, zatrudnienie. Pod red. H. Madurowicz-Urbańskiej. Kraków 1981, s. 73.

${ }^{30}$ W. Szajnocha, Górnictwo, hutnictwo..., s. 12. 
produkcja soli potasowych w Galicji stale rosła - ponad dwudziestoczterokrotnie w przypadku soli potasowej mielonej, a w przypadku soli potasowej w kawałkach ponad pięćdziesięciosiedmiokrotnie. W roku wystawy lwowskiej (1894) zbyt soli potasowej mielonej był większy niż jej produkcja w tymże roku. Zbyt - 12105 cetn. metr. (1 210,5 t), produkcja - 7427 cetn. metr. $(742,7$ t). Świadczyło to o sprzedaży soli wcześniej wyprodukowanej i zmagazynowanej (do 1894 roku zbyt tylko w Galicji). W następnych latach galicyjska sól potasowa była sprzedawana również poza Galicję (Morawy, Śląsk, Styria, Austria Dolna, Austria Górna, Dalmacja, Bukowina) ${ }^{31}$, co niewątpliwie pozwoliło znacznie zwiększyć produkcję tego rodzaju soli.

Tabela 1. Wielkość produkcji soli potasowej w latach 1894 i 1911 w Galicji.

Wielkość produkcji w cetnarach metrycznych, w nawiasie w tonach.

\begin{tabular}{|l|l|l|}
\hline Rok & Wielkość produkcji soli w kawałkach & Wielkość produkcji soli mielonej \\
\hline 1894 & $3500(196)$ & $7427(415,9)$ \\
\hline 1911 & $200000(11200)$ & $172000(9632)$ \\
\hline
\end{tabular}

Źródło: J. Bar, P. Franaszek, Informator statystyczny do dziejów przemysłu w Galicji. Górnictwo i hutnictwo, produkcja, ceny, zbyt, przedsiębiorstwa, zatrudnienie. Pod red. H. MadurowiczUrbańskiej. Kraków 1981, tab. 3, s. 73-74.

Siła nabywcza ludności Galicji była zbyt słaba, aby stać się znaczącym klientem dla przemysłu solnego (sól spożywcza), pomimo nominalnie spadającej ceny. Społeczeństwo galicyjskie było po prostu zbyt biedne. Rynek wewnętrzny nie poszerzał się. Dlatego też część soli spożywczej eksportowano z Galicji na Morawy, do Dolnej Austrii czy też na Śląsk. Wielkość produkcji solnej w Galicji do 1911 roku wzrosła niewiele ${ }^{32}$, osiągając w tymże roku 1412151 cetn. metr., tj. 141 215,1 t. Dane te świadczą o bardzo powolnym rozwoju przemysłu solnego Galicji, jednak liczba osób w nim zatrudnionych pomimo relatywnie małego wzrostu produkcji stale rosła: w 1877 roku wynosiła 1430 osób, w 1892 roku -1685 , a w roku $1911-3403$ osoby $^{33}$.

${ }^{31}$ J. Bar, P. Franaszek, Informator..., tab. 3, 4, s. 73, 75.

${ }^{32}$ Produkcja do 1911 roku oscylowała wokół 1,4 miliona cetn. metr. (140 tys. t). Od 1903 roku nieco wzrosła, $\mathrm{z}$ rekordowym rokiem 1907, kiedy wyniosła 1,8 miliona cetn. metr. (180 tys. t). W latach wcześniejszych bywało, że produkcja była większa. Zob. J. Bar, P. Franaszek, Informator..., tab. 3, 4, s. 73, 75 .

${ }^{33}$ J. Bar, P. Franaszek, Informator..., tab. 3, 4, s. 73, 75. 
Tabela 2. Wielkość produkcji soli kamiennej, warzonej, przemysłowej oraz ich wartość produkcji. Liczba kopalń-salin w Galicji w latach 1877 i 1892.

Wielkość produkcji w cetnarach metrycznych, w nawiasie w tonach. Wartość produkcji w złotych reńskich.

\begin{tabular}{|c|c|c|c|c|c|c|}
\hline Rok & $\begin{array}{c}\text { Sól kamienna } \\
\text { wielkość } \\
\text { produkcji }\end{array}$ & $\begin{array}{c}\text { Sól warzona } \\
\text { wielkość } \\
\text { produkcji }\end{array}$ & $\begin{array}{c}\text { Sól przemysłowa } \\
\text { wielkość produkcji }\end{array}$ & $\begin{array}{c}\text { Produkcja } \\
\text { razem }\end{array}$ & $\begin{array}{c}\text { Wartość } \\
\text { produkcji }\end{array}$ & $\begin{array}{c}\text { Liczba } \\
\text { kopalń-salin }\end{array}$ \\
\hline 1877 & $\begin{array}{c}529116 \\
(29630,4)\end{array}$ & $\begin{array}{c}424623 \\
(23778,8)\end{array}$ & $\begin{array}{c}101822 \\
(5702,03)\end{array}$ & $\begin{array}{c}1055561 \\
(59111,4)\end{array}$ & 9807901 & - \\
\hline 1892 & 328110 & 496918 & 401088 & 1226116 & 7685318 & $\begin{array}{c}2 \text { kopalnie } \\
9 \text { salin } \\
(18374,1)\end{array}$ \\
\hline
\end{tabular}

Źródło: J. Bar, P. Franaszek, Informator statystyczny do dziejów przemysłu w Galicji. Górnictwo i hutnictwo, produkcja, ceny, zbyt, przedsiębiorstwa, zatrudnienie. Pod red. H. MadurowiczUrbańskiej. Kraków 1981, tab. 1, s. 68, 70.

Węgiel kamienny wydobywano w Galicji w Tenczynku, Sierszy i okolicy Jaworzna. W roku wystawy lwowskiej z 1877 roku wydobycie w Galicji wynosiło

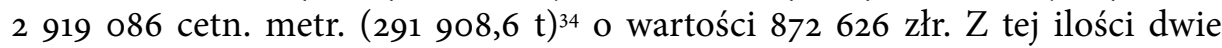
trzecie przypadało na kopalnie w Jaworznie, blisko jedna trzecia na kopalnie hr. Andrzeja Potockiego w Sierszy, natomiast reszta -57618 cetn. metr. $(5761,8$ t) na mniejsze kopalnie Tenczynka ${ }^{35}$. W kolejnych latach produkcja węgla kamiennego rosła, osiągając w 1892 roku 632 479,5 t (wartość 1117053 złr), a w roku 1894700 660,4 t (wartość 1208395 złr) ${ }^{36}$. Liczby te wskazują, że pomimo wzrostu produkcji o ponad 100 proc. w latach 1877-1894 realna wartość węgla kamiennego spadła, ponieważ wartość produkcji wrosła tylko o ok. 40 proc. ${ }^{37}$. Powodem takiego stanu rzeczy był fakt, że górnictwo krakowsko-jaworznickie musiało konkurować $\mathrm{z}$ węglem morawskim i górnośląskim. Poza tym węgiel galicyjski w porównaniu z konkurencją miał niską wartość kaloryczną. Nie był też chroniony taryfami celnymi, jak to miało miejsce w przypadku Królestwa Polskiego. Poza tym węgiel górnośląski był uprzywilejowany

${ }^{34}$ Wacław Długoborski podaje, że produkcja węgla kamiennego w Galicji w 1877 roku wynosiła 291,9 tys. ton. Zob. W. Długoborski, Górnictwo i hutnictwo do 1918 r. W: Uprzemysłowienie ziem Polskich w XIX i XX wieku. Studia i materiały. Pod red. I. Pietrzak-Pawłowskiej. Wrocław 1970, s. 132.

${ }^{35}$ F. Bujak, Galicja. T. 1: Kraj, ludność, społeczeństwo, rolnictwo. Lwów-Warszawa 1908, s. 23.

${ }^{36}$ Obliczenia autora na podstawie: J. Bar, P. Franaszek, Informator..., s. 84.

${ }^{37}$ Obliczenia autora. 
pod względem taryf kolejowych. Przejazd 10-tonowego wagonu z galicyjskiej Sierszy do Tarnowa kosztował 59,6 koron, a z górnośląskich Mysłowic do Tarnowa 55 koron. Wobec takiej sytuacji węgiel galicyjski musiał tanieć, aby był konkurencyjny. W chwili gdy kosztował 4,4 korony za tonę (w roku 1899), węgiel wydobywany w innych częściach monarchii kosztował około 7,8 koron, dlatego też produkcja kopalń galicyjskich stanowiła zaledwie $60-80$ proc. ${ }^{8}$ ich możliwości. W dobie Powszechnej Wystawy Krajowej 1894 roku (dane z roku 1892) Galicja importowała co najmniej $3 \mathrm{mln}$ cetn. metr. (3o tys. t) węgla, co stanowiło prawie połowę wydobycia galicyjskiego. To niekorzystne zjawisko potęgował fakt, że cała produkcja jaworznicka sprzedawana była tylko na rynku lokalnym, to jest w Krakowie i okolicy, oraz kolejom państwowym ${ }^{39}$. Produkcja galicyjskiego węgla kamiennego wynosiła zaledwie 6,84 proc. całej przedlitawskiej. Jednakże przy tak niekorzystnych okolicznościach możemy mówić o ciągłym rozwoju tej gałęzi górnictwa.

$\mathrm{Na}$ Wystawie zaprezentowała się kopalnia hr. Andrzeja Potockiego z Sierszy. Dla zwiedzających ustawiono sztolnię ułożoną z bloków węglowych i płyt cynkowych. Pokazano szereg narzędzi górniczych oraz okazałą bryłę węglową o wadze kilkunastu cetnarów. Wyeksponowano cenne rysunki przekrojów kopalnianych, tabele statystyczne, graficzne obrazujące produkcję górniczą. Jak się wydaje, wykorzystano tu w dużej mierze uwagi i doświadczenie po wystawie krakowskiej z 1887 roku $^{40}$. Pokazano również okazy skamielin z pokładów węglowych. Górnictwo jaworzyńskie, znajdujące się ówcześnie głównie w rękach braci Guttmanów, nie zaprezentowało się w Wystawie ${ }^{41}$.

Węgiel brunatny wydobywany był w Galicji w miejscowościach: Grudna Dolna koło Dębicy, Glinko i Skwarzawa koło Żółkwi oraz Myszyn i Nowosielica pod Kołomyją. Były to w ówczesnym czasie główne miejsca - oprócz mniejszych na Podkarpaciu i Podolu - wydobycia węgla brunatnego ${ }^{42}$. Skala wydobycia tego rodzaju węgla była bardzo niewielka. Jednakże na przestrzeni lat 1877-1892 wielkość produkcji wzrosła o 15402,7 t, a jej wartość o $68728 \mathrm{złr}^{43}$. W 1877 roku wydobyto w całej Galicji 38582 cetn. metr. (3 858,2 t) o wartości

${ }^{38}$ W. Długoborski, Górnictwo..., s. 162.

39 Tamże, s. 5.

${ }^{40}$ W. Szajnocha, Przemysł górniczy galicyjski na Wystawie Krajowej w Krakowie w r. 1887. Lwów 1888, s. 16.

${ }^{41}$ W. Szajnocha, Górnictwo, hutnictwo..., s. 5.

${ }^{42}$ F. Bujak, Galicja..., s. 25.

${ }^{43}$ Obliczenia autora. 
16264 złr, natomiast w 1892 roku 192609 cetn. metr. (19 260,9 t) o wartości 84992 złr $^{44}$. Udział Galicji w całej produkcji Austrii wynosił zaledwie 0,12 proc.45. Skromna ekspozycja odzwierciedlała tę niewielką skalę produkcji. Znajdowała się ona we wschodnim skrzydle głównego gmachu przemysłowego. Prezentowane były bryły węgla z Grudnej Dolnej w pawilonie ks. Eustachego Sanguszki. W pawilonie hr. Romana Potockiego pokazywano mapy, przekroje, fotografie kopalń z Glińska, Grudnej Dolnej oraz Myszyny, Dżurowa - te dwie ostatnie były własnością Stanisława Szczepanowskiego.

Galicja nie była również potentatem w produkcji żelaza. Na wystawie lwowskiej było ono obecne jedynie w dwóch prywatnych pawilonach arcyksięcia Albrechta i hr. Andrzeja Potockiego. W 1877 roku wydobyto w Galicji 43794 cetn. metr. (4 379,4 t) o wartości 17253 złr. A w 1892, 79766 cetn. metr. (7 976,6 t) wartości $19434 \mathrm{złr}^{46}$. Rudy te były głównie wywożone do wielkich hut Śląska pruskiego. W Galicji istniała tylko jedna huta żelaza w Węgierskiej Górce (własność arcyksięcia Albrechta) ${ }^{47}$, gdzie w roku $1892 \mathrm{w}$ dwóch piecach wytopiono surowego lanego żelaza 30377 cetn. metr. (3 037,7 t) o wartości 209431 złr. Natomiast w roku 187725669 cetn. metr. (2 566,9 t) o wartości $324421 \mathrm{złr}^{48}$. Wytapiane tam żelazo pochodziło głównie $\mathrm{z}$ rud węgierskich, śląskich, pruskich, rosyjskich i hiszpańskich. Widać zatem, że nawet jedyna galicyjska huta żelaza nie opierała się na surowcu rodzimym. Ruda żelaza znajdowała się na Wystawie prawie wyłącznie w pawilonie hr. Potockiego. Natomiast bardzo cenione wyroby $\mathrm{z}$ lanego żelaza znajdowały się $\mathrm{w}$ pawilonie arcyksięcia Albrechta. W innych prywatnych pawilonach znaleźć można było także tzw. rudę darniową.

Jeszcze mniejszą rolę niż żelazo odgrywał w Galicji ołów. W większej ilości ruda ołowiu znajdowała się jedynie w okręgu krakowskim. Niemal cała ilość wydobycia była wywożona do pruskiego Śląska ${ }^{49}$. W samej Galicji wytapiany był tylko tzw. surowy ołów jako produkt uboczny w nielicznych hutach cynkowych, a jego ilości były bardzo małe. W 1892 roku wyprodukowano tylko 118 cetn. metr. $(11,8 \mathrm{t})$, jeszcze mniej w 1894 - 79 cetn. metr. $(7,9$ t),

\footnotetext{
${ }_{44}$ J. Bar, P. Franaszek, Informator..., s. 94-95.

${ }^{45}$ W. Szajnocha, Górnictwo, hutnictwo..., s. 6.

${ }^{46}$ J. Bar, P. Franaszek, Informator..., s. 102, 104.

${ }^{47}$ F. Bujak, Galicja..., s. 27-28.

${ }_{48}$ J. Bar, P. Franaszek, Informator..., s. 148.

${ }^{49}$ F. Bujak, Galicja..., s. 26.
} 
Galicyjskie górnictwo i hutnictwo w świetle Powszechnej Wystawy Krajowej... 167

o wartości odpowiednio 1517 i 898 złr $^{50}$. Główna kopalnia ołowiu w Kątach pod Chrzanowem nie wzięła udziału w Wystawie. Rudy ołowiu można było zobaczyć jedynie w pawilonie hr. Andrzeja Potockiego oraz w zbiorze mineralogicznym pokazanym przez C.K. Starostwo Górnicze w Krakowie ${ }^{51}$. Jednakże samo wydobycie rudy ołowiu pomiędzy rokiem 1877 a 1892 gwałtownie wzrosło. W kolejnych latach produkcja nadal rosła, jednak z dużymi wahaniami (w niektórych latach następował spadek); tendencja była jednak wzrostowa.

Tabela 3. Wielkość i wartość produkcji rudy ołowiu w Galicji w latach 1877, 1892 i 1894. Wielkość produkcji w cetnarach metrycznych, w nawiasie w tonach. Wartość produkcji w złotych reńskich

\begin{tabular}{|l|l|l|}
\hline Rok & Wielkość produkcji & Wartość produkcji \\
\hline 1877 & $4214(421,4)$ & brak danych \\
\hline 1892 & $32596(3259,6)$ & 124270 \\
\hline 1894 & $11001(1100,1)$ & 42445 \\
\hline
\end{tabular}

Źródło: J. Bar, P. Franaszek, Informator statystyczny do dziejów przemysłu w Galicji. Górnictwo i hutnictwo, produkcja, ceny, zbyt, przedsiębiorstwa, zatrudnienie. Pod red. H. MadurowiczUrbańskiej. Kraków 1981, tab. 17, s. 118-120.

Cynk na Wystawie był wyeksponowany w dużych ilościach, adekwatnie do znacznej jego produkcji. Niemal całość wydobycia z okręgu krakowskiego była przetapiana w dwóch hutach - w hucie w Krzu koło Sierszy, należącej do hr. Andrzeja Potockiego oraz w hucie w Niedzieliskach, należącej do Hugona Loebbeckego. Produkcja galicyjska wynosiła 36,2 proc. całej produkcji Austrii (Styria i Kraina produkujące cynk). W pawilonie hr. Andrzeja Potockiego można było oglądać rudy, płyty cynkowe, które odbijały się srebrzyście na tle czarnego węgla. Prezentowano mapy kopalń galmanowych oraz, jak twierdził Władysław Szajnocha, ciekawe i pouczające przekroje-mapy, które dawały doskonały obraz cynkowego górnictwa i hutnictwa. Jak zauważa Szajnocha, wspomniana huta w Niedzieliskach, która była umieszczona w oddziale górniczym pawilonu ministerstwa rolnictwa, zajmowała się głównie wyrobem bieli cynkowej (tlenek cynku),

${ }^{50}$ J. Bar, P. Franaszek, Informator..., tabela 33, s. 171.

${ }^{51}$ W. Szajnocha, Górnictwo, hutnictwo..., s. 7. 
której w 1892 roku wyprodukowała 20454 cetn. metr. (2 045,4 t) o wartości $490896 \mathrm{złr}^{52}$. Służyła ona do produkcji farb i była eksportowana do całej Europy. Warto w tym miejscu zauważyć, że jej wielkość produkcji i wartość przewyższały wielkość i wartość produkcji tzw. cynku surowego w całej Galicji w 1892 roku.

Tabela 4. Wielkość i wartość produkcji rudy cynku w Galicji w latach 1877, 1892 oraz 1894. Wielkość produkcji w cetnarach metrycznych, w nawiasie w tonach. Wartość produkcji w złotych reńskich

\begin{tabular}{|l|l|l|}
\hline Rok & Wielkość produkcji & Wartość produkcji \\
\hline 1877 & $133820(13382)$ & brak danych \\
\hline 1892 & $137692(13769,2)$ & 72301 \\
\hline 1894 & $89814(8981,4)$ & 68517 \\
\hline
\end{tabular}

Źródło: J. Bar, P. Franaszek, Informator statystyczny do dziejów przemysłu w Galicji. Górnictwo i hutnictwo, produkcja, ceny, zbyt, przedsiębiorstwa, zatrudnienie. Pod red. H. Madurowicz-

Urbańskiej. Kraków 1981, tab. 14, s. 111-112.

Tabela 5. Wielkość i wartość produkcji cynku w Galicji w latach 1877, 1892 oraz 1894. Wielkość produkcji w cetnarach metrycznych, w nawiasie w tonach. Wartość produkcji w złotych reńskich

\begin{tabular}{|l|l|l|}
\hline Rok & Wielkość produkcji & Wartość produkcji \\
\hline 1877 & $18138(1813,8)$ & 351174 \\
\hline 1892 & $18995(1899,5)$ & 443732 \\
\hline 1894 & $26160(2616)$ & 475517 \\
\hline
\end{tabular}

Źródło: J. Bar, P. Franaszek, Informator statystyczny do dziejów przemysłu w Galicji. Górnictwo i hutnictwo, produkcja, ceny, zbyt, przedsiębiorstwa, zatrudnienie. Pod red. H. MadurowiczUrbańskiej. Kraków 1981, tabela 30, s. 165-166.

Prowadzona na skalę przemysłową eksploatacja ropy naftowej w Galicji rozpoczęła się w chwili, gdy w lipcu 1953 roku ${ }^{53}$ za sprawą Jana Zeha i Ignacego Łukasiewicza, którym udało się uzyskać oczyszczoną ropę, po raz pierwszy zapłonęła lampa naftowa. Pierwszą instytucją publiczną oświetlaną w taki sposób był szpital

52 Tamże, s. 8.

${ }_{53}$ P. Franaszek, Jak kopano za ropa $w$ Galicji. „Biuletyn Muzeum Inżynierii Miejskiej w Krakowie" 2002, z. 2, s. 20. 
powszechny we Lwowie. Szpital ten był oświetlany naftą, którą uzyskał Łukasiewicz z ropy borysławskiej dostarczanej przez Abrahama Schreinera. Ważną datą w historii galicyjskiej ropy było zastosowanie w 1882 roku tak zwanego głębokiego wiercenia systemem kanadyjskim - najpierw przez firmę Bergheim i Mac Garvey w Uhercach koło Leska, a następnie w Krygu koło Gorlic. Kanadyjski sposób wiercenia szybko rozprzestrzenił się na terenie całego Podkarpacia, wzrastało zatem zapotrzebowanie na sprzęt wiertniczy. W odpowiedzi na nie w początku lat 8o. XIX wieku ${ }^{54}$ w Gliniku Mariampolskim powstała Fabryka Maszyn i Narzędzi Wiertniczych, częściowo ograniczając zależność od zagranicznych dostawców55.

W 1894 roku w Galicji poszukiwaniem i wydobyciem ropy zajmowało się przeszło 300 przedsiębiorstw górniczych, które zatrudniały około 3 tys. robotników. Roczna produkcja (1894) wynosiła 1119302 cetn. metr. (111 930,2 t) ropy o wartości $3252554 \mathrm{złr}^{56}$. W latach 70.-90. wielkość produkcji gwałtownie wzrosła, jednakże cena za 1 cetn. metr. zmniejszyła się od 9,93 złr w 1877 roku do 3,5 złr w roku 1892. Spadek cen surowca w pierwszej kolejności spowodowany był konkurencją ropy amerykańskiej, następnie wprowadzeniem podatku konsumpcyjnego oraz konkurencją tzw. falsyfikatu kaukaskiego ${ }^{57}$.

Tabela 6. Wielkość i wartość produkcji ropy naftowej w Galicji w latach 1877, 1892 oraz 1894. Wielkość produkcji w cetnarach metrycznych, w nawiasie w tonach. Wartość produkcji w złotych reńskich

\begin{tabular}{|l|l|l|}
\hline Rok & Wielkość produkcji & Wartość produkcji \\
\hline 1877 & $120979(12097,9)$ & 1202097 \\
\hline 1892 & $898713(89871,3)$ & 2742724 \\
\hline 1894 & $1119302(111930,2)$ & 3252554 \\
\hline
\end{tabular}

Źródło: J. Bar, P. Franaszek, Informator statystyczny do dziejów przemysłu w Galicji. Górnictwo i hutnictwo, produkcja, ceny, zbyt, przedsiębiorstwa, zatrudnienie. Pod red. H. MadurowiczUrbańskiej. Kraków 1981, tab. 22, s. 130-131.

${ }_{54}$ Założone w 1883 roku przy rafinerii w Gliniku Mariampolskim warsztaty mechaniczne dały początek Fabryce Maszyn i Narzędzi Wiertniczych. Zob. P. Franaszek, Fabryka Maszyn i Narzędzi Wiertniczych w Gliniku Mariampolskim (do 1918 roku). W: Z dziejów przemystu przed 1945 rokiem. Pod red. J. Chumińskiego, M. Zawadki. Wrocław 2012, s. 164.

${ }_{55}$ J. Cząstka, A. Giermański, K. Mischke, Wiertnictwo naftowe. W: Historia polskiego przemysłu naftowego. T. 1. Pod red. R. Wolwowicza. Brzozów 1994, s. 218.

${ }_{56}^{56}$ J. Bar, P. Franaszek, Informator..., s. 128.

${ }^{57}$ W. Szajnocha, Górnictwo, hutnictwo..., s. 14-15. 
W Galicji istniało 41 destylarń nafty. W 1893 roku wszystkie galicyjskie destylarnie wyprodukowały 390988 cetn. metr. (39 o98,8 t) nafty różnej jakości, od której zapłacono niebagatelną kwotę podatku konsumpcyjnego - 2541422 złr ${ }^{58}$. Wydobywaniem wosku ziemnego zajmowało się w 1892 roku 80 przedsiębiorstw górniczych zatrudniających 5 tys. robotników, ich produkcja roczna wynosiła przeszło 56376 cetn. metr. (5 637,6 t) o wartości 1508778 złrº. Jednakże wydobycie wosku ziemnego w latach 1877 i 1894 malało i w kolejnych latach również miało tendencję spadkową.

Tabela 7. Wielkość i wartość produkcji wosku ziemnego (ozokerytu) w Galicji w latach 1877, 1892 oraz 1894.

Wielkość produkcji w cetnarach metrycznych, w nawiasie w tonach. Wartość produkcji w złotych reńskich

\begin{tabular}{|l|l|l|}
\hline Rok & Wielkość produkcji & Wartość produkcji \\
\hline 1877 & $89610(8961)$ & 2306127 \\
\hline 1892 & $56248(5624,8)$ & 1268335 \\
\hline 1894 & $67431(6743,1)$ & 1572095 \\
\hline
\end{tabular}

Źródło: J. Bar, P. Franaszek, Informator statystyczny do dziejów przemysłu w Galicji. Górnictwo i hutnictwo, produkcja, ceny, zbyt, przedsiębiorstwa, zatrudnienie. Pod red. H. MadurowiczUrbańskiej. Kraków 1981, tab. 24, s. 136-138.

Jak przedstawiano dorobek Galicji na polu przemysłu naftowego na placu wystawy? Największą ciekawość zwiedzających wzbudzała wieża wiertnicza o kształcie piramidy o wysokości 30 metrów, w której maszyna parowa napędzała świder, mogący według planów osiągnąć głębokość $600 \mathrm{~m}$. Oprócz wieży wymienić należy pompę, która wypompowywała ropę i wodę $\mathrm{z}$ trzech szybów jednocześnie. Jednakże gdyby zaszła taka potrzeba, mogła wypompowywać ropę jednocześnie z 80 szybów w promieniu pół mili od urządzenia. W głównym pawilonie Krajowego Towarzystwa Naftowego można było zobaczyć akwarele i fotografie kopalń nafty oraz przekroje geologiczne. Jak oceniano, najlepiej prezentowały się kopalnie ropy Elliota i Parkinsona w Ropience koło Olszanicy oraz kopalnie Towarzystwa Hanowersko-Galicyjskiego. Na ścianach wisiały obrazy Tadeusza Rybkowskiego, przedstawiające kopalnie

\footnotetext{
${ }^{88}$ „Gazeta Lwowska” R. 84: 1894, nr 176 z dn. 3 VIII, s. 5.

59 J. Bar, P. Franaszek, Informator..., s. 138.
} 
Galicyjskie górnictwo i hutnictwo w świetle Powszechnej Wystawy Krajowej... 171

ropy $\mathrm{w}$ Lipinach, Wietrznie, Równem, Bóbrce oraz Potoku, obok obrazów kopalń wisiały ich przekroje. W części pawilonu kierownik biura górniczego Wydziału Krajowego inżynier Leon Syroczyński zbudował piramidę, która składała się z okazów surowca $\mathrm{z}$ wszystkich kopalń galicyjskich. Zbiór ten dawał zwiedzającym możliwość przeglądu ropy każdej kopalni pod względem zabarwienia, właściwości gatunkowych oraz innych parametrów. Pokazano również mapę prezentującą produkcję ropy i wosku ziemnego w Galicji od 1877 do 1893 roku, $\mathrm{z}$ uwzględnieniem cen i wartości produkcji.

W innej części pawilonu umieszczono dział destylacji nafty. Szczególną uwagę zwracały tam produkty rafinerii dr. Mikołaja Fedorowicza. Jej wyroby uchodziły za jedne $\mathrm{z}$ najlepszych. W pogrupowanych słojach stały obok siebie: olej wulkanowy, olej smarowy, olej salonowy, benzyna oczyszczona, nafta gospodarska, nafta salonowa, nafta cesarska, łuski parafinowe, koks itp. Obok mieściła się wystawa produktów Adama Skrzyńskiego z Libuszy, na którą uwagę zwracała mapa przekrojów szybowych w Libuszy, pokazująca, w jaki sposób ropa, przechodząc rozmaite warstwy ziemi, zmienia swoją naturalną ciemną barwę na zieloną. W tym samym pawilonie firma Fibicha i Stawiarskiego pokazała imitację skał (z koksu) oraz produkty swojej destylarni z Chorkówki. Szczyt prezentowanej skały zdobił wielkich rozmiarów klosz z czystego szkła, zawierający oczyszczoną bezbarwną naftę.

$\mathrm{Na}$ wystawie naftowej swoje miejsce miał tak zwany magazyn, w którym to przedstawiano narzędzia wiertnicze używane w kopalniach naftowych. Narzędzi tych dostarczała fabryka maszyn Kazimierza Lipińskiego z Sanoka. Obok magazynu na wystawie była również kuźnia, kotłownia oraz barak z masy papierowej dla robotników, wyprodukowany w fabryce Szeligi-Łyszkiewicza we Lwowie. Dawał się on łatwo rozbierać na części i przenosić z miejsca na miejsce. Pomiędzy pawilonami leżały stosy rur używanych do głębokich wierceń, a produkowanych przez czeską fabrykę Mannesmanna z Chomutova. Kopalnia Jadwigi Starszewskiej i Seweryna Stawiarskiego z Lipinek zaprezentowała ręczny warsztat wiertniczy. Krajowe Towarzystwo Naftowe pokazało narzędzia używane w kopalnictwie naftowym w Galicji w latach 1860-1883, aby pokazać rozwój techniczny w tej dziedzinie na przestrzeni lat ${ }^{60}$.

Dla ekspozycji wosku ziemnego Towarzystwo Naftowe przewidziało osobny pawilon. Zaprezentowano w nim kopalnie wosku ziemnego w Borysławiu. We wnętrzu pawilonu mieścił się 11-metrowy szyb, do którego wchodziło się po

${ }^{60}$ W. Szajnocha, Górnictwo, hutnictwo..., s. 12-16. 
specjalnych drabinkach prowadzących do chodnika mającego $31 \mathrm{~m}$ długości. W chodniku oraz w czołach „zrobów” zjazdowych oświetlonych lampami umieszczone były pokłady wosku ziemnego. Znajdował się tam także używany w kopalniach borysławskich tzw. wózek „fedrunkowy”. Zejście w dół szybu dawało zwiedzającym rzeczywisty obraz kopalni wosku ziemnego. Do roku 1894 na powierzchni około 150 ha wykopano ponad 13 tys. szybów, $\mathrm{z}$ tego tylko około 2 tys. było w użytku. Produkcja wosku ziemnego (ozokerytu) w latach 70. XIX wieku była znacznie większa niż w roku 1894, czego główną przyczyną była rabunkowa eksploatacja najpłycej położonych warstw. W latach 9o. Borysław pomimo zastoju był głównym producentem cerezyny w Europie. Produkcja wosku od roku 1963 aż do 1892 przyniosła co najmniej 6o mln złr zysku w całej Galicji, z tego właściciele Borysławia zarobili 59 milionów ${ }^{61}$.

Jako wystawcy w pawilonie wosku ziemnego zaprezentowały się firmy: Gartenberg, Lauterbach, Goldhammer i Wagmann - wszystkie z Drohobycza. Prezentowały one wosk surowy, cerezynę, parafinę, tłuszcz do smarowania skór, świece (także kolorowe). Firma Goldhammer i Wagmann, która wcześniej na wystawie w Chicago dostała złoty medal za swoje produkty, reprezentowała jedyną w całej Galicji fabrykę cerezyny. Pokazano również wyroby galanteryjno-plastyczne z przetopionego wosku ziemnego, które prezentował $\mathrm{P}$. H. (imiona nieznane) Małukiewicz z Myszyna ${ }^{62}$. W dziale naftowym nie zabrakło również wyrobów asfaltowych prezentowanych przez lwowską fabrykę asfaltu Szeligi i Łyszkiewicza. Pokazano bitum asfaltowy, masę asfaltową, zagęszczony gudron oraz asfalt służący do osuszania wilgotnych pomieszczeń. $Z$ nowości pokazanych na wystawie naftowej można wymienić motor benzynowy pokazany przez fabrykę Langera i Wolfa z Wiednia. Podobne motory znajdowały się również na wystawie w hali maszyn. Motor znalazł zastosowanie w restauracji Jankowskiego do wyrobu tak zwanych kiełbasek „parowych” - trzy urządzenia napędzane motorem siekały mięso na różne sposoby. We Lwowie w tym czasie w różnych fabrykach znajdowało się około 30 motorów benzynowych lub naftowych. Stopniowo wypierały one motory napędzane gazem, jednakże ten proces postępował bardzo powoli ze względu na wysoką cenę samego motoru oraz podatek konsumpcyjny. Motorem naftowym na Wystawie poruszana była kolejka wąskotorowa, umieszczona dla celów demonstracyjnych na placu wystawy - każdy za opłatą mógł odbyć nią krótką przejażdżkę. Generalna

\footnotetext{
${ }^{61}$ Tamże, s. 13.

62 „Gazeta Lwowska” R. 84: 1894, nr 178 z dn. 5 VIII, s. 5.
} 
Galicyjskie górnictwo i hutnictwo w świetle Powszechnej Wystawy Krajowej... 173

dyrekcja austriackich kolei państwowych zaprezentowała $\mathrm{w}$ hali maszyn lokomotywę, która mogła być napędzana węglem i odpadkami z produktów naftowych.

Według Władysława Szajnochy wystawa naftowa w porównaniu z wystawą lwowską z 1877 czy nawet krakowską z 1887 roku potwierdziła dalszy rozwój przemysłu naftowego w Galicji. Wystawa naftowa była jedną z najciekawszych, najbardziej obleganych przez zwiedzających ${ }^{63}$. Oceniając ogólny stan galicyjskiego górnictwa i hutnictwa, Szajnocha stwierdzał, że stan jego nie był zły, ponieważ we wszystkich gałęziach oprócz produkcji soli, ozokerytu oraz żelaza nastąpił rozwój - przede wszystkim w zakresie przemysłu naftowego $^{64}$. Ocena ta jednak wydaje się nieprecyzyjna, ponieważ - jak próbowałem wykazać - miał miejsce wzrost produkcji soli, a od zakończenia wystawy nastąpił gwałtowny wzrost produkcji soli potasowej. Również wytop żelaza pomimo swojej niewielkiej produkcji nie zmniejszał się, lecz powoli wzrastał (przy znacznym spadku wartości i obcym surowcu). Jedynie produkcja wosku ziemnego (ozokerytu) nie przedstawiała dobrych perspektyw na przyszłość i w konsekwencji zrezygnowano $\mathrm{z}$ jego wydobycia.

Niewątpliwie wystawiennictwo było jednym $\mathrm{z}$ elementów stymulujących gospodarkę nie tylko w zakresie przemysłu naftowego, ale i pozostałych dziedzin. Sam zaś rozwój, zwłaszcza górnictwa naftowego, sprzyjał pozytywnym przemianom cywilizacyjnym ${ }^{65}$.

Powszechna Wystawa Krajowa we Lwowie odbiła się szerokim echem nie tylko w polskiej, ale i zagranicznej prasie. „Kurier Lwowski” oraz „Gazeta Narodowa” przedrukowywały niektóre artykuły lub zamieszczały na swoich łamach ich streszczenia. O lwowskiej wystawie pisały m.in. czasopisma niemieckie i austriackie: „Allgemeine Zeitung”, „Wiener Zeitung”, „Vaterland”, „Deutches Volksblatt”, „Weltblat”, „Fremdenblatt”, „National Zeitung”, „Pressse”; czeskie „Politik”, „Národní Politika”, „Národní Listy”, „Prager Zeitung”, „Bohemia”, „Hlas Národa”; chicagowska „Tribune”, bułgarska „Swoboda”. Z zaboru pruskiego „Dziennik Poznański”, który wysłał na wystawę własnego korespondenta, z zaboru

${ }^{63}$ W. Szajnocha, Górnictwo, hutnictwo..., s. 12-16.

${ }^{64}$ Tamże, s. 20.

${ }_{55}$ P. Franaszek, Między nowoczesnością a zacofaniem. Rola przemysłu naftowego w modernizacji gospodarki i społeczeństwa Galicji na przełomie XIX i XX wieku. W: Między zacofaniem a modernizacją. Społeczno-gospodarcze problemy ziem polskich na przestrzeni wieków. Pod red. E. Kościk, T. Głowińskiego. Wrocław 2009, s. 415. 
rosyjskiego - warszawska "Gazeta Polska" ${ }^{66}$. Zastanawiającym pozostaje jednak fakt nieprzywoływania przez prasę lwowską anonsów prasy węgierskiej. Ich brak mógł wynikać $\mathrm{z}$ dwóch przyczyn. Po pierwsze $\mathrm{z}$ braku zainteresowania - co wydaje się jednak mało prawdopodobne, choćby ze względu na fakt, że wystawę odwiedził cesarz Franciszek Józef I, co nie mogło zostać niezauważone. Po drugie - co bardziej prawdopodobne - prasa węgierska mogła być bardziej krytyczna w stosunku do wystawy. W prasie polskiej zamieszczano informacje o wystawie pochodzące z zagranicznych wydawnictw raczej tylko o wydźwięku pozytywnym.

Wyłaniający się z wystawy obraz galicyjskiego górnictwa i hutnictwa był niewątpliwie przejaskrawiony i pokazywał je zbyt optymistycznie w odniesieniu do ich rzeczywistej kondycji. Jednakże założenia wystawiennicze są takie, aby pokazywać to, co najlepsze. Specjaliści branżowi doceniali wystawiennictwo jako formę i narzędzie aktywizujące rozwój oraz sposób oceny jego poziomu. Można jednak wyciągać wnioski również na podstawie tego, czego nie zaprezentowano. Wystawiennictwo zwiększało niewątpliwie kapitał społeczny, co mogło owocować kolejnymi inicjatywami. Już w dwudziestoleciu międzywojennym zauważono, że Powszechnej Wystawie Krajowej we Lwowie w 1894 w pewnym stopniu udało się pobudzić życie ekonomiczne Galicji ${ }^{67}$, co było niezaprzeczalnym sukcesem.

\section{Streszczenie}

Galicyjskie górnictwo i hutnictwo w świetle Powszechnej Wystawy Krajowej we Lwowie w 1894 roku

Powszechna Wystawa Krajowa zorganizowana we Lwowie w 1894 roku, w setną rocznicę insurekcji kościuszkowskiej, miała pokazać dorobek ekonomiczno-kulturowy Ga-

${ }^{66}$ „Kurier Lwowski” R. 12: 1894: nr 6 z dn. 6 I, s. 2; nr 11 z dn. 11 I, s. 3; nr 25 z dn. 25 I, s. 2; nr 27 Z dn. 27 III, s. 3; nr 154 z dn. 5 VI, s. 3; nr 168 z dn. 19 VI, s. 1; nr 172 z dn. 23 VI, s. 2. „Gazeta Narodowa" R. 34: 1894, $\mathrm{nr} 130 \mathrm{z}$ dn. 9 VI, s. 1-2.

${ }^{67}$ K. Ołdziejewski, Wystawy powszechne. Poznań 1928, s. 108; S. Hoszowski, Ekonomiczny rozwój Lwowa w latach 1772-1914. Lwów 1935, s. 59. 
licji od czasu uzyskania przez nią autonomii politycznej. Miała objąć swoim zakresem życie duchowe i materialne mieszkańców Galicji i nie tylko, w tym przede wszystkim Polaków, dać przykłady bogactwa jej płodów, górnictwa, hutnictwa, rolnictwa, leśnictwa, łowiectwa; przedstawić życie ludności, zabytki sztuki ludowej, tzw. przemysł domowy, rękodzieła; pokazać rozwój instytucji finansowych, administracji publicznej, opieki zdrowotnej, komunikacji, inżynierii, budownictwa, literatury, szkolnictwa ogólnego i zawodowego, rozwój sztuk pięknych i architektury. Miała stać się okazją do integracji narodowej Polaków. Artykuł analizuje tylko fragment jej ogromnej spuścizny w zakresie dorobku galicyjskiego górnictwa i hutnictwa. Ukazuje dynamiczny rozwój przemysłu naftowego, wzrost produkcji soli, wytopu żelaza, węgla kamiennego i brunatnego. Jedynie produkcja wosku ziemnego (ozokerytu) nie dawała dobrych perspektyw i w konsekwencji zrezygnowano z jego wydobycia. Wystawiennictwo było jednym z elementów stymulujących gospodarkę $w$ wielu dziedzinach. Sam zaś rozwój, zwłaszcza górnictwa naftowego, sprzyjał pozytywnym przemianom cywilizacyjnym. Wystawiennictwo zwiększyło niewątpliwie kapitał społeczny, co mogło owocować kolejnymi inicjatywami.

\section{Słowa kluczowe}

wystawa, powszechna wystawa, Lwów, 1894, górnictwo, hutnictwo, Galicja, autonomia galicyjska

\section{Summary}

\section{Galician mining and metallurgy in the light of the General Regional Exhibition of Lviv in 1894}

The General Regional Exhibition of Lviv was organized in 1894, on the 100 year anniversary of the Kosciuszko Uprising of 1794. The Exhibition was meant to demonstrate Galicia's economical and cultural progress since its gaining political autonomy and to become an opportunity for the national integration of Poles. The Exhibition displays included various thematic groups which were devoted to both spiritual and material aspects of life in Galicia and were meant to show the abundance of its crops and produce, mining and metallurgy, agriculture, forestry and hunting. The shows pictured everyday life of the inhabitants of Galicia, its folk art, so-called domestic industry and craftwork. 
Other sections of the Exhibition demonstrated the development of the Galician financial institutions, public administration, healthcare, communication, engineering, construction, literature, general and vocational education and the bloom of the fine arts and architecture.

The article analyzes only some parts of the great legacy of the Exhibition, its scope focuses on mining and metallurgy. The text points out the dynamic development of the oil industry and the increase in the branches such as: salt production, iron smelting, and brown and hard coal extraction. The only branch of the Galicia's economy which had not offered good perspectives and was thus soon discontinued had been the production of earthwax (ozocerite).

The organization of the exhibitions of such sort was regarded at that time as one of the best ways to stimulate economy and benefit the regions. The actual development itself, especially of the oil mining, aided many positive social and cultural changes and undoubtedly increased the societal potential and might have resulted in further initiatives.

\section{Keywords}

Galicia, mining, metallurgy, exhibition, Lviv, 1894, political autonomy

\section{Bibliografia}

\section{Źródła drukowane}

Bar J., Franaszek P., Informator statystyczny do dziejów przemysłu w Galicji. Górnictwo i hutnictwo, produkcja, ceny, zbyt, przedsiębiorstwa, zatrudnienie. Pod red. H. Madurowicz-Urbańskiej. Kraków 1981.

Powszechna Wystawa Krajowa we Lwowie. Regulamin Organizacyjny Komitetu głównego powszechnej Wystawy Krajowej we Lwowie roku 1894. Lwów 1892.

\section{Opracowania}

Broński K., Galicja w dobie autonomii wobec wyzwań nowoczesności. W: Między zacofaniem a modernizacja. Społeczno-gospodarcze problemy ziem polskich na przestrzeni wieków. Pod red. E. Kościk, T. Głowińskiego. Wrocław 2009, s. 395-412.

Broński K., Rozwój gospodarczy większych miast galicyjskich w okresie autonomii. Kraków 2003.

Bujak F., Galicja. T. 1: Kraj, ludność, społeczeństwo, rolnictwo. Lwów-Warszawa 1908.

Bujak F., Wieś zachodniogalicyjska u schyłku XIX w. Lwów 1904.

Cząstka J., Giermański A., Mischke K., Wiertnictwo naftowe. W: Historia polskiego przemystu naftowego. T. 1. Pod red. R. Wolwowicza. Brzozów 1994, s. 214-248. 
Galicyjskie górnictwo i hutnictwo w świetle Powszechnej Wystawy Krajowej... 177

Długoborski W., Górnictwo i hutnictwo do 1918 r. W: Uprzemysłowienie ziem Polskich w XIX i XX wieku. Studia i materiały. Pod red. I. Pietrzak Pawłowskiej. Wrocław 1970, s. 109-176.

Franaszek P., Fabryka Maszyn i Narzędzi Wiertniczych w Gliniku Mariampolskim (do 1918 roku). W: $Z$ dziejów przemysłu przed 1945 rokiem. Pod red. J. Chumińskiego, M. Zawadki. Wrocław 2012, s. 161-175.

Franaszek P., Jak kopano za ropa w Galicji. „Biuletyn Muzeum Inżynierii Miejskiej w Krakowie" 2002, z. 2, s. 20-28.

Franaszek P., Między nowoczesnościa a zacofaniem. Rola przemystu naftowego w modernizacji gospodarki i społeczeństwa Galicji na przełomie XIX i XX wieku. W: Między zacofaniem a modernizacją. Spoleczno-gospodarcze problemy ziem polskich na przestrzeni wieków. Pod red. E. Kościk, T. Głowińskiego. Wrocław 2009, s. 413-428.

Hoszowski S., Ekonomiczny rozwój Lwowa w latach 1772-1914. Lwów 1935.

Kulczykowski M., Modernizacja społeczeństwa galicyjskiego w warunkach autonomii politycznej. W: Samomodernizacja społeczeństw w XIX wieku. Irlandczycy, Czesi, Polacy. Pod red. L. Trzeciakowskiego, K. Makowskiego. Poznań 1999, s. 107-129.

Ołdziejewski K., Wystawy powszechne. Poznań 1928.

Powszechna Wystawa Krajowa 1894 r. i siły produkcyjne kraju. T. 1, z. 1. Lwów 1897.

Przegląd Wystawy Powszechnej w Wiedniu w 1873. Pod red. S. Kossutha. Warszawa 1875.

Rutowski T., W sprawie przemysłu krajowego. Kraków 1883.

Szajnocha W., Górnictwo, hutnictwo, przemysł naftowy, materiały budowlane. W: Powszechna Wystawa Krajowa we Lwowie w 1894. T. 1. Kraków 1896, s. 1-20.

Szajnocha W., Przemyst górniczy galicyjski na Wystawie Krajowej w Krakowie w r. 1887. Lwów 1888.

Szczepanowski S., Nędza Galicji w cyfrach. Lwów 1888.

Prasa

„Gazeta Lwowska” R. 84: 1894.

„Gazeta Narodowa” R. 34: 1894.

„Kurier Lwowski” R. 12: 1894. 
